\title{
Which species of small mammals tolerate highly urbanized areas - the study in Warsaw agglomeration and surroundings
}

\author{
Grzegorz Lesiński ${ }^{1 *}$, Jakub Gryz² ${ }^{2}$ Dagny Krauze-Gryz ${ }^{3}$ \\ Jerzy Romanowski ${ }^{4}$, Przemysław Stolarz ${ }^{5}$ \\ 1 Faculty of Animal Sciences, Warsaw University of Life Sciences - SGGW, Ciszewskiego 8, 02-786 Warsaw, Poland, \\ 2 Department of Forest Ecology, Forest Research Institute, Sękocin Stary, Braci Leśnej 3, 05-090 Raszyn, Poland \\ 3 Faculty of Forestry, Warsaw University of Life Sciences - SGGW, Nowoursynowska 159C, 02-787 Warsaw, Poland \\ 4 Faculty of Biology and Environmental Sciences UKSW, Wóycickiego 1/3, 01-938 Warsaw, Poland \\ 5 Centre of Human Ecology, Kościuszki 24, 05-075 Warsaw, Poland \\ *e-mail: glesinski@wp.pl
}

\section{Summary}

The degree of penetration of urban habitats by small terrestrial mammals was studied in Warsaw agglomeration and in adjacent areas up to $50 \mathrm{~km}$ from the city centre. Study material consisted of pellets of the tawny owl Strix aluco collected in 85 sites, which contained 15,152 remains of individuals of small mammals. The species that penetrated city agglomeration most intensively were: Apodemus agrarius, Mus musculus, Talpa europaea, Rattus norvegicus and Microtus subterraneus. Most central sites of these species were situated 1.3-2.3 km from the city centre. Microtus agrestis, Mustela nivalis, Arvicola amphibius, Neomys fodiens, Muscardinus avellanarius and Sicista betulina showed the lowest degree of penetration of an urban agglomeration (sites closest to the city centre: 8.2, $8.6,8.6,11.2,17.8$ and $20.2 \mathrm{~km}$, respectively). Species, whose share among the owls' prey decreased most with the distance from the city centre, were: A. agrarius and T. europaea. The reverse pattern was found for M. agrestis and $M$. avellanarius. Small terrestrial mammals are sensitive to the proceeding urbanization and the central part of Warsaw agglomeration is penetrated by only $1 / 3$ of species of the local fauna.

\section{Key words}

Rodentia, Soricomorpha, urbanization, urban green areas, habitat fragmentation

\section{Introduction}

Small terrestrial mammal species face many obstacles when settling in highly urbanized areas. Large city agglomerations are characterised by a small contribution of habitats close to the natural (forests, parks, water bodies) with a substantial part of built-up areas and accompanying infrastructure. Habitats less modified by human activity are often fragmented and their patches of various sizes are spatially isolated. In central districts, wild mammal species function in metapopulations. This pattern negatively affects species diversity of mammal fauna since not all of the species are adapted to such a type of functioning 


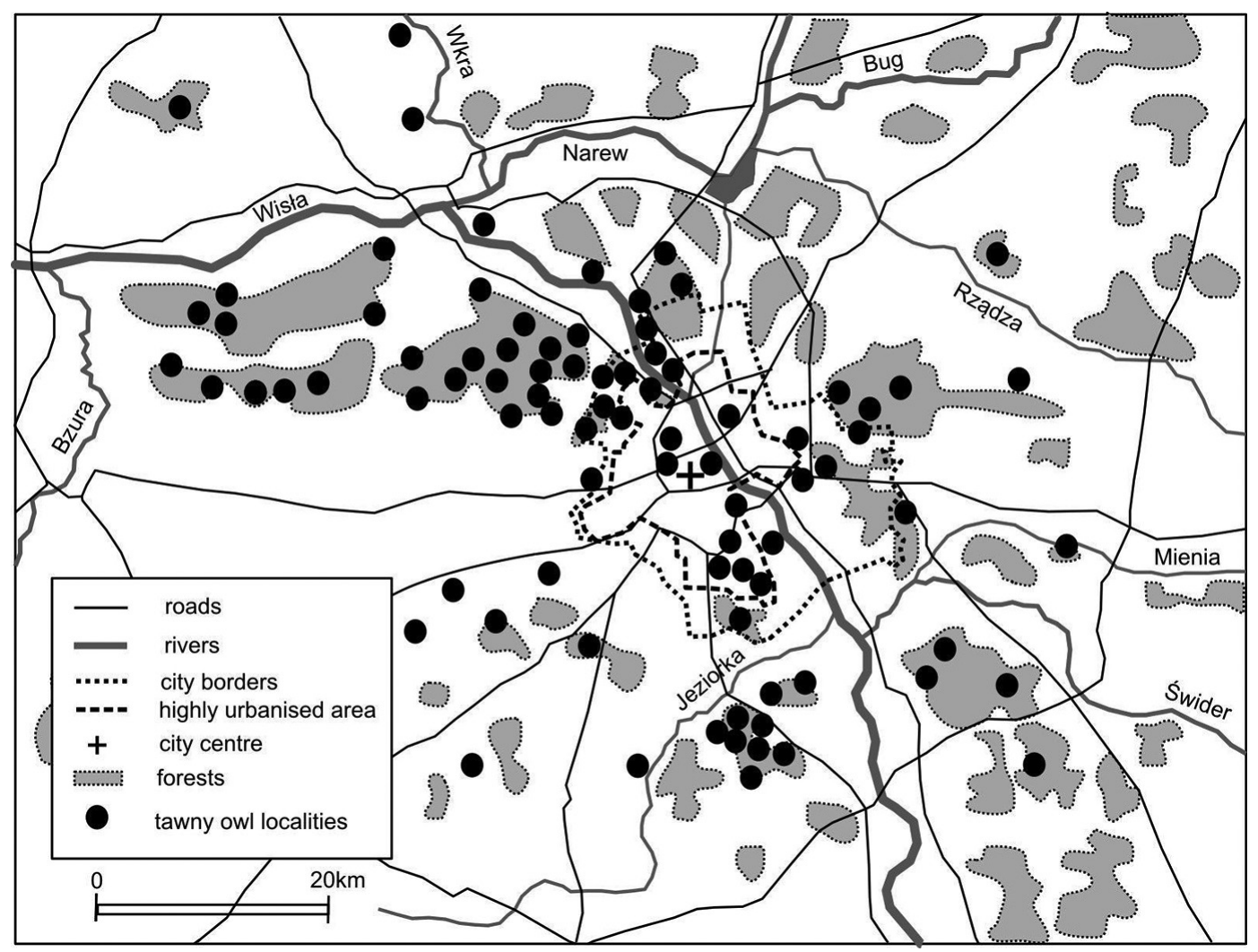

Fig. 1. Distribution of study sites in Warsaw and surrounding areas

(Dickman and Doncaster 1987, Baker et al. 2003, McKinney 2008, Gomes et al. 2011, Łopucki et al. 2013, Klimant et al. 2017). In addition, city agglomerations preserve but a few wetland habitats. One may expect that this deficiency limits or totally eliminates small mammals that prefer peatlands or bog woodlands. Several studies performed in the last years were focused on factors influencing urban communities of mammals (van der Ree and McCarthy 2005, Isaac et al. 2014, Villaseñor et al. 2014, 2015).

Communities of small mammals in Warsaw were the subject of some studies, especially in comparative aspect with habitats outside the city (Andrzejewski et al. 1978, Goszczyński et al. 1993, Gortat et al. 2014). It has been found that one of the specific features of small mammal communities in the city is a low species diversity resulting from the dominance of an abundant population of Apodemus agrarius. Studies carried out in the second half of the $2 \mathrm{O}^{\text {th }}$ century demonstrated also a significant penetration of the city by Microtus subterraneus, less frequent and numerous in habitats outside the city (Goszczyński et al. 1993). Despite these findings we still do not know, how far a particular species (especially those, which show a clear tendency of avoiding urban areas) can inhabit a city zone.

The aim of this study was to determine the structure of small terrestrial mammal community inhabiting city agglomeration and its surroundings to indicate species that avoid relatively dense human settlements and to assess how far they might penetrate a large city tolerating dispersion and isolation of their preferred habitats. One might expect that mammals closely associated with forests and wetlands will mainly avoid towns. Moreover, functioning 
Table 1. Distribution of study site distances from the city centre. $\mathrm{N}$ - number of the sites studied. $S_{100}$ - number of sites where at least 100 individuals of mammals were identified

\begin{tabular}{lll}
\hline Distance $(\mathrm{km})$ & $\mathrm{N}$ & $\mathrm{S}_{100}$ \\
\hline $0-10.0$ & 15 & 6 \\
\hline $10.1-20.0$ & 26 & 14 \\
\hline $20.1-30.0$ & 28 & 11 \\
\hline $30.1-40.0$ & 12 & 3 \\
\hline $40.1-50.0$ & 4 & 2 \\
\hline
\end{tabular}

in city metapopulations in habitats less favourable for wildlife (i.e. built-up areas), is possible only for the species with high dispersal abilities.

\section{Materials and methods}

\subsection{Study area}

Studies were carried out in Warsaw (central Poland) and in adjacent areas within $50 \mathrm{~km}$ radius from the city centre (Fig. 1). Warsaw agglomeration is inhabited by 1.7 million people and occupies an area of $517 \mathrm{~km}^{2}$ within its administration borders. Larger forest complexes neighbour Warsaw from the north-east and south-east, smaller and more fragmented forests - from the east and north.

\subsection{Data collection}

Data on species composition and community structure of small mammals were obtained from the analysis of diet of the tawny owl Strix aluco. This method allows for relatively fast and more effective assessment of species composition compared with studies based on trap methods (Heisler et al. 2015). The owl is an opportunistic predator, which hunts on small mammals without a strong preference to individual species (Wendland 1984, Lesiński et al. 2008). One may thus assume that the diet of S. aluco can show the species composition of small mammal communities. The share of particular species in the diet of S. aluco is useful in comparisons between sites and habitats (Żmihorski et al. 2008).

Tawny owl pellets were prepared after soaking in water. The species of prey were determined based mainly on skulls and mandibles, less frequently on skeleton bones (humeral bones of mole Talpa europaea) by adopting the features given in the key edited by Pucek (1984) and those from comparative collections. The number of individuals was determined taking into account the minimum number of recognizable items.

Samples were collected once or several times in different seasons of a year from 85 sites, which represented wooded habitats (parks, forests) or their outskirts - the main habitats of this owl species. For some sites, earlier published data were used (Gryz et al. 2008, Lesiński and Gryz 2008, Stolarz and Lesiński 2012, Lesiński et al. 2013, Romanowski et al. 2014) supplemented with data collected later. Distribution of the sites (Table 1) shows that many of them (41 in total) were located within the city agglomeration from $1.3 \mathrm{~km}$ (the closest to the city centre site studied) to $10 \mathrm{~km}$ from the city centre (very dense development) and from 10.1 to $20 \mathrm{~km}$ from the city centre (outskirts and suburban areas). Sites more that $20 \mathrm{~km}$ away from the city centre (4. in total) represented habitats remote from the city agglomeration. In total, study material collected in the years 1982-2015 contained 15,152 remains of individuals of small mammals.

\subsection{Data analysis}

In material collected in 36 sites at least 100 individuals of small mammals were identified (Table 1). These samples were large enough for further statistical analyses - calculating the median distance from the city 
Table 2. General characteristics of the records of particular mammal species. Significant values are given in bold.

$\mathrm{N}$ - total number of sites, $\mathrm{N}_{10 \mathrm{~km}}$ - number of sites within $10 \mathrm{~km}$ radius from the centre (per $15 \mathrm{sites}$ ), Closest site - distance from the centre to the closest site $(\mathrm{km}), \mathrm{M}$ - median of the distance $(\mathrm{km})$ from the centre (upper and lower quartile) [Number of sites among those with a minimum of 100 identified individuals of mammals], $r_{s}$ - Spearman coefficient of correlation between the share of the species in owl's diet and the distance from the city centre

\begin{tabular}{|c|c|c|c|c|c|}
\hline Species & $\mathrm{N}$ & $\mathrm{N}_{10 \mathrm{~km}}$ & Closest site & $M$ & $r_{s}$ \\
\hline Myodes glareolus & 70 & 7 & 7.5 & $18.4(13.1-23.5)[34]$ & $0.458(p=0.005)$ \\
\hline Apodemus agrarius & 63 & 14 & 1.3 & $16.3(11.2-23.5)[34]$ & $-0.745(p<0.001)$ \\
\hline Apodemus flavicollis & 59 & 5 & 7.5 & $18.3(11.3-23.5)[35]$ & $0.002(p=0.993)$ \\
\hline Sorex araneus & 53 & 5 & 7.5 & $18.4(11.3-23.5)[34]$ & $0.239(p=0.161)$ \\
\hline Microtus arvalis & 49 & 8 & 4.9 & $15.1(11.2-20.7)[30]$ & $0.084(p=0.625)$ \\
\hline Mus musculus & 44 & 10 & 1.3 & $14.8(11.1-20.4)[29]$ & $-0.236(p=0.167)$ \\
\hline Sorex minutus & 40 & 3 & 7.5 & $20.1(14.0-24.2)[29]$ & $0.407(p=0.014)$ \\
\hline Talpa europaea & 39 & 7 & 2.3 & $15.1(11.1-20.4)[30]$ & $-0.536(p<0.001)$ \\
\hline Rattus norvegicus & 38 & 9 & 2.3 & $14.8(11.1-20.2)[30]$ & $-0.531(p=0.001)$ \\
\hline Micromys minutus & 37 & 4 & 4.4 & $18.5(13.1-22.4)[27]$ & $0.007(p=0.966)$ \\
\hline Microtus oeconomus & 35 & 4 & 7.5 & $19.3(13.8-27.5)[26]$ & $0.242(p=0.155)$ \\
\hline Apodemus sylvaticus & 33 & 3 & 8.0 & $18.4(13.8-29.6)[22]$ & $0.116(p=0.499)$ \\
\hline Microtus agrestis & 19 & 1 & 8.2 & $20.4(18.3-31.1)[13]$ & $0.460(p=0.005)$ \\
\hline Muscardinus avellanarius & 13 & 0 & 17.8 & $20.7(20.2-31.1)[9]$ & $0.496(p=0.002)$ \\
\hline Microtus subterraneus & 12 & 3 & 2.3 & $11.3(10.5-29.6)[10]$ & $-0.240(p=0.159)$ \\
\hline Neomys fodiens & 11 & 0 & 11.2 & $20.3(18.5-23.5)[10]$ & $0.305(p=0.071)$ \\
\hline Arvicola amphibius & 9 & 1 & 8.6 & $19.4(14.8-20.4)[6]$ & $0.097(p=0.573)$ \\
\hline Mustela nivalis & 5 & 1 & 8.6 & $13.1(11.3-29.6)[5]$ & $-0.030(p=0.861)$ \\
\hline Sicista betulina & 1 & 0 & 20.2 & - & - \\
\hline
\end{tabular}

centre and the share of a given species in the tawny owl diet. Comparisons of the median distances of records from the city centre were made by means of Mann-Whitney test. The relationship between the share of a species in the owl's diet (the number of individuals of a given species divided by the number of individuals of all species) and the distance from the centre of Warsaw was assessed by means of Spearman correlation coefficient. Statistical significance was adopted at $\mathrm{p}<0.05$. Calculations were performed with the Statistica 10 software.

\section{Results}

Analyses involved 19 species of small mammals. This group included common species (Myodes glareolus, A. agrarius, Apodemus flavicollis, Sorex araneus - in more than
50 sites) and very rarely (e.g. Sicista betulina - at 1 site) preyed upon by S. aluco. The most common species found in 70 sites was M. glareolus. For the individual mammal species, the sites closest to the city centre were spread from $1.3 \mathrm{~km}$ to $20.2 \mathrm{~km}$ apart (Table 2). Based on this parameter, one may find that the species most intensively penetrating the city were: $A$. agrarius, $M u s$ musculus, Rattus norvegicus and Talpa europaea (the sites 1.3 to $2.3 \mathrm{~km}$ away from the city centre) while the weakest invaders were: Neomys fodiens, Muscardinus avellanarius and S. betulina (11.2-20.2 km from the centre). Most sites within the radius of $10 \mathrm{~km}$ from the centre of Warsaw (14 out of 15 analysed) were inhabited by $A$. agrarius (Table 2). 
Table 3. Differences between the medians of the site distances from the city centre for selected pairs of species. Statistically significant values (Mann-Whitney test) are given in bold

\begin{tabular}{lcc}
\hline Compared pair of species & Z & $p$ \\
\hline Sorex araneus vs. Talpa europaea & 0.82 & 0.412 \\
\hline Sorex minutus vs. Sorex araneus & 1.30 & 0.192 \\
\hline Neomys fodiens vs. Sorex araneus & 1.83 & 0.067 \\
\hline Microtus oeconomus vs. Microtus arvalis & 0.69 & 0.490 \\
\hline Microtus agrestis vs. Microtus arvalis & 1.85 & 0.062 \\
\hline Microtus agrestis vs. Mus musculus & $\mathbf{2 . 1 0}$ & $\mathbf{0 . 0 3 6}$ \\
\hline Microtus agrestis vs. Rattus norvegicus & $\mathbf{2 . 1 4}$ & $\mathbf{0 . 0 3 2}$ \\
\hline Myodes glareolus vs. Apodemus flavicollis & 0.19 & 0.848 \\
\hline Apodemus flavicollis vs. Apodemus agrarius & 0.34 & 0.732 \\
\hline Microtus agrestis vs. Apodemus agrarius & 1.82 & 0.067 \\
\hline Muscardinus avellanarius vs. Talpa europaea & $\mathbf{2 . 5 7}$ & $\mathbf{0 . 0 1 0}$ \\
\hline Muscardinus avellanarius vs. Microtus subterraneus & $\mathbf{2 . 3 0}$ & $\mathbf{0 . 0 2 2}$ \\
\hline Muscardinus avellanarius vs. Myodes glareolus & $\mathbf{2 . 0 8}$ & $\mathbf{0 . 0 3 8}$ \\
\hline Muscardinus avellanarius vs. Mus musculus & $\mathbf{2 . 6 4}$ & $\mathbf{0 . 0 0 8}$ \\
\hline Muscardinus avellanarius vs. Rattus norvegicus & $\mathbf{2 . 5 7}$ & $\mathbf{0 . 0 1 0}$ \\
\hline Muscardinus avellanarius vs. Apodemus agrarius & $\mathbf{2 . 2 9}$ & $\mathbf{0 . 0 2 2}$ \\
\hline
\end{tabular}

The presence of most species in the sites with minimum 100 identified individuals was quite variable with respect to the distance from the centre. Hence, the medians of this characteristic were usually ten to twenty kilometres. The highest values - more than $20 \mathrm{~km}$ (indicating the avoidance of the city) were noted for Sorex minutus, N. fodiens, Microtus agrestis and M. avellanarius (Table 2).

Some species showed statistically significant relationships between their share in the diet of $S$. aluco and the distance from the city centre (Table 2). Those more frequently hunted in habitats outside the city were: $M$. avellanarius, $M$. agrestis, $M$. glareolus and S. minutus; the reverse relationship (an increase of the proportion in the diet towards the centre) was found for: A. agrarius, T. europaea and $R$. norvegicus. Within the genus Sorex, the species best tolerating the increasing development of urban areas was $S$. araneus. Among the common and numerous forest rodents, $M$. glareolus avoided the city agglomeration more than $A$. flavicollis.

The presence itself of a given species in particular sites was not a parameter strongly determining its association with the city. Statistically significant differences between the medians of distances from the city centre were demonstrated in only few cases when pairs of species were compared. $M$. agrestis was distinct as compared to synanthropic species ( $M$. musculus, $R$. norvegicus). Most separate species in this aspect appeared M. avellanarius (Table 3 ).

\section{Discussion}

Urban communities of animals, compared with those living outside the cities, usually show marked species impoverishment (Clergeau et al. 2001, McKinney 2008, Klimant et al. 2017). Relatively few species are able to adapt to specific habitats characterized by human activities. Urban communities are dominated by a small group of species able to inhabit anthropogenically transformed habitats (Woolfenden and Rohwer 1969). Results presented here also demonstrate a distinct decline in the number of small mammal species in the central part of the city. Seven species were found within the radius of $5 \mathrm{~km}$ from the city centre while 
17 species were noted in the whole town and its suburbia (Table 2).

A specific feature of Polish towns is the abundance of $A$. agrarius in communities of small mammals - this was also noted in Warsaw (Andrzejewski et al. 1978, Goszczyński et al. 1993, Gryz et al. 2008, Gortat et al. 2014). Local densities of this rodent are 5 to 10 times higher in Warsaw than in habitats outside the town (Gliwicz et al. 1994). The species was abundant and frequently recorded in other towns of Eastern Europe (Tikhonova et al. 2012), though in Western Europe, e.g. in the British Isles, the dominant urban species is Apodemus sylvaticus (Baker et al. 2003). The results presented here on the degree of penetration of the Warsaw agglomeration by $A$. agrarius confirm the recent findings. The species belongs to a small group of animals noted in the direct vicinity of the central point of Warsaw. Similar pattern was observed for M. subterraneus, which synurbic populations are known not only in Warsaw, but also in other cities, e.g. in Slovakia (Klimant et al. 2017).

The similar pattern of occurrence was shown for $R$. norvegicus, which is understandable having in mind that it is a strongly synanthropic species more closely associated with built-up areas (Traweger et al. 2006) than $A$. agrarius, which finds favourable conditions in urban greens, in parks (Babińska-Werka et al. 1979). Similarly, an intensive penetration of Warsaw agglomeration was noted for another synanthropic rodent $-M$. musculus, though its share in the community of small mammals was smaller. The latter species has been frequently noted as abundant in many towns both in Europe (Tikhonova et al. 2012, Kelcey 2015) and in other continents (Advani 1995, Gomez et al. 2008).

T. europaea has also penetrated deep into the built-up areas, this species finds favourable conditions in the town greens. The species is eurytopic and tolerates markedly transformed areas inhabiting both large forest complexes and city lawns
(Amori et al. 2008). Open areas in the Warsaw agglomeration were also settled by $M$. arvalis, which could be found relatively close to the centre. This is a proof of a remarkable adaptability of this species in habitat selection.

Species poorly penetrating urban areas (M. avellanarius, $N$. fodiens, $M$. agrestis, Arvicola amphibius, S. betulina, S.minutus and $M$. glareolus) presumably did not find suitable living conditions in the city. The first five species are neither common nor numerous even in the outskirts of Warsaw (Pucek and Raczyński 1983, Lesiński and Gryz 2008, Lesiński et al. 2013, Romanowski et al. 2014), which is an effect of a limited availability of the appropriate habitats. Most of them dwell in the substantially moist habitats, which are practically absent in the large city. A nearly significant coefficient of correlation between the percent of $N$. fodiens in the total number of animals hunted and the distance from the centre of Warsaw was documented. The relationship seems probable but small sample (10 sites) makes tough evidence difficult. This species is associated with water bodies and usually avoids urban areas (Goszczyński et al. 1993, Zalewski 1994, Gortat et al. 2014).

Noteworthy, A. flavicollis has recently been more and more often noted in Warsaw greens, which might indicate an intensification of its penetration (Gortat et al. 2014, Krauze-Gryz et al. 2015). In the 1970 and 1980 os the species was noted in Warsaw less frequently and contributed less to the community structure of small mammals (Goszczyński et al. 1993). In our studies, the site of $A$. flavicollis closest to the centre was situated at a distance of $7.5 \mathrm{~km}$ (Table 2) while in other studies it was noted even closer (about $3.5 \mathrm{~km}$ ) in Park Skaryszewski (Krauze-Gryz et al. 2015).

Data presented in this paper indicate that small terrestrial mammals are sensitive to the advancement of urbanization. The most developed central zone of the city is penetrated by about $1 / 3$ of species representing local fauna, and no more than 
three species (A. agrarius, T. europaea and $R$. norvegicus) might be considered as well adapted to living in the city greens under a strong human impact. The enrichment of small mammal communities by immigrating species could be facilitated by planting green belts (ecological corridors), to connect the existing parks and larger green areas, and by removing barriers such as large traffic arteries through, for example, building passages under roads. Where natural conditions permit, one may create nature reserves facilitating the restoration of small mammal communities (Lesiński and Gryz 2012).

\section{Acknowledgements}

We are grateful to all, who helped to collect the study material.

\section{References}

Advani R. 1995, Mouse populations and their control in New York city, International Biodeterioration, Biodegradation, 36, 135-141.

Amori G., Hutterer R., Mitsain G., Yigit N., Kryštufek B., Palomo L.J. 20o8, Talpa europaea. The IUCN Red List of Threatened Species 2008: e.T41481A10462965. http://dx.doi.org/10.2305/ IUCN.UK.2008.RLTS.T41481A10462965.en.

Andrzejewski R., Babińska-Werka J., Gliwicz J., Goszczyński J. 1978, Synurbization processes in population of Apodemus agrarius. I. Characteristics of populations in an urbanization gradient, Acta Theriologica, 23, 341-358.

Babińska-Werka J., Gliwicz J., Goszczyński J. 1979, Synurbization processes in a population of Apodemus agrarius. II. Habitats of the Striped Field Mouse in town, Acta Theriologica, 24, 405-415.

Baker P.J., Ansell R.J., Dodds P.A., Webber C.E., Harris S. 2003, Factors affecting the distribution of small mammals in an urban area, Mammal Review, 33, 95-100.

Clergeau P., Jokimäki J. , Savard J.-P. L. 2001, Are urban bird communities influenced by the bird diversity of adjacent landscapes? Journal of Applied Ecology, 38, 1122-1134.

Dickman C.R., Doncaster C.P. 1987, The ecology of small mammals in urban habitats. I. Populations in a patchy environment, Journal of Animal Ecology, 56, 629-640.
Gliwicz J., Goszczyński J., Luniak M. 1994, Characteristic features of animal populations under synurbization - the case of the Blackbird and of the Striped Field Mouse, Memorabilia Zoologica, 49, 237-244.

Gomes V., Ribeiro R., Carretero M.A. 2011, Effects of urban habitat fragmentation on common small mammals: species versus communities, Biodiversity and Conservation, 20, 3577-3590.

Gomez M. D., Priotto J., Provensal M. C., Steinmann A., Castillo E., Polop J. J. 2008, A population study of house mice (Mus musculus) inhabiting different habitats in an Argentine urban area. International Biodeterioration, Biodegradation, 62, 270-273.

Gortat T., Barkowska M., Gryczyńska-Siemiątkowska A., Pieniążek A., Kozakiewicz A. , Kozakiewicz M. 2014, The effect of urbanization - small mammal communities in a gradient of human pressure in Warsaw city, Poland, Polish Journal of Ecology, $62,163-172$.

Goszczyński J., Jabłoński P., Lesiński G., Romanowski J. 1993. Variation in diet of Tawny Owl Strix aluco L. along an urbanization gradient,. Acta Ornithologica, 27, 113-123.

Gryz J., Krauze D. , Goszczyński J. 20o8, The small mammals of Warsaw as based on the analysis of tawny owl (Strix aluco) pellets, Annales Zoologici Fennici, 45, 281-285.

Heisler L.M., Somers C.M., Poulin R.G. 2015, Owl pellets: a more effective alternative to conventional trapping for broad-scale studies of small mammal communities, Methods in Ecology and Evolution, 7, 96-103.

Isaac B., White J., Ierodiaconou D., Cooke R. 2014, Simplification of arboreal marsupial assemblages in response to increasing urbanization. PLoS ONE 9, 3, e91049.

Kelcey J. G. (ed.) 2015. Vertebrates and invertebrates of European cities: selected non-avian fauna. Springer Science + Business Media, New York.

Klimant P., Klimantová A., Baláž I., Jakab I., Tulis F., Rybanský L.,Vadel. L', Krumpálová Z. 2017. Small mammals in an urban area: habitat preferences and urban-rural gradient in Nitra city, Slovakia. Polish Journal of Ecology, 65, 144-157.

Krauze-Gryz D., Lesiński G., Pieniążek A., Romanowski J., Owsianka M., Prus M., 2015, Mammals of the Skaryszewski Park in Warsaw, in: Romanowski J. (ed.), “Skaryszewski Park in Warsaw: 
nature and management", Wydaw. UKSW, Warsaw, 215-226. [in Polish],

Lesiński G., Gryz J. 2008, Localities of three rare mammal species in central and northeastern Poland, Fragmenta Faunistica, 51, 63-69.

Lesiński G., Gryz J. 2012, How protecting a suburban forest as a natural reserve effected small mammal communities, Urban Ecosystems, 15, 103-110.

Lesiński G., Gryz J., Kowalski M. 2008, Does the diet of an opportunistic raptor, the tawny owl Strix aluco, reflect long-term changes in bat abundance? A test in central Poland, Folia Zoologica, $57,258-263$.

Lesiński G., Romanowski J., Gryz J., Olszewski A., Kowalski M., Krauze-Gryz D., Olech B., Pepłowska -Marczak D., Tarłowski A. 2013, Small mammals of Kampinos National Park and its protection zone, as revealed by analyses of the diet of tawny owls Strix aluco, Fragmenta Faunistica, 56, 65-81.

Łopucki R., Mróz I., Berliński Ł., Burzych M. 2013, Effects of urbanization on small-mammal communities and the population structure of synurbic species: an example of a medium-sized city, Canadian Journal of Zoology, 91, 554-561.

McKinney M. L. 2008, Effects of urbanization on species richness: A review of plants and animals, Urban Ecosystems, 11, 161-176.

Pucek Z. (ed.) 1984, Klucz do oznaczania ssaków Polski, PWN, Warsaw.

Pucek Z., Raczyński J. (eds) 1983, Atlas rozmieszczenia ssaków w Polsce, PWN, Warsaw.

van der Ree R., McCarthy M. A. 2005, Inferring persistence of indigenous mammals in response to urbanization, Animal Conservation, 8, 309-319.

Romanowski J., Tarłowski A., Lesiński G., Olszewski A. 2014, Drobne ssaki Chojnowskiego Parku Krajobrazowego w pokarmie puszczyka Strix aluco, Chrońmy Przyrodę Ojczystą 70, 63-67.

Stolarz P., Lesiński G. 2012, Kręgowce w pokarmie puszczyka Strix aluco w rezerwacie Bagno Jacka $i$ na terenach przylegtych, Kulon, 17, 107-110.
Tikhonova G.N., Tikhonov I.A., Kotenkova E.V., Munteanu A.I., Uspenskaya I.G., Konovalov Y.N., Burlaku V.I., Kiku V.F., Georgitsa S.D., Karaman N.K., Nistreanu V.B., Maltsev A.N. 2012, Comparative analysis of small mammal communities in Cisinau and Yaroslavl, two European cities located in different biomes, Russian Journal of Ecology, 43, 236-242.

Traweger D., Travnitzky R., Moser C., Walzer Ch., Bernatzky G. 2006, Habitat preferences and distribution of the brown rat (Rattus norvegicus Berk.) in the city of Salzburg (Austria): implications for an urban rat management, Journal of Pest Science, 79, 113-125.

Villaseñor N., Blanchard W., Driscoll D. A., Gibbons P., Lindenmayer D. B. 2015, Strong influence of local habitat structure on mammals reveals mismatch with edge effects models, Landscape Ecology, 30, 229-245.

Villaseñor N.R., Driscoll D.A., Escobar M.A. H., Gibbons P., Lindenmayer D.B. 2014, Urbanization impacts on mammals across urban-forest edges and a predictive model of edge effects, PLoS ONE, 9, 5, e97036.

Wendland V. 1984, The influence of prey fluctuations on the breeding success of the Tawny Owl Strix aluco,. Ibis, 126, 284-295.

Woolfenden G.E., Rohwer S.A. 1969, Breeding birds in a Florida suburb, Bulletin of Florida State Museum, 13, 1-83.

Zalewski A. 1994, Diet of urban and suburban tawny owls (Strix aluco) in the breeding season. Journal of Raptor Research, 28, 246-252.

Żmihorski M., Balčiauskienè L., Romanowski J. 2008, Small mammals in the diet of the Tawny Owl (Strix aluco L.) in Central European lowland, Polish Journal of Ecology, 56, 693-70o. 


\section{Które gatunki małych ssaków tolerują tereny silnie zurbanizowane - badania w aglomeracji warszawskiej i na terenach otaczających}

\section{Streszczenie}

Celem pracy było określenie stopnia zasiedlania terenów zurbanizowanych przez poszczególne gatunki małych ssaków związanych z podłożem, a co za tym idzie ich tolerancji na zmiany w środowiskach wywołane urbanizacją i częstą penetracją ludzką. Badania przeprowadzono w aglomeracji warszawskiej i na terenach ją otaczających w promieniu $50 \mathrm{~km}$ od centrum miasta. Wykorzystano zbiory zrzutek puszczyka Strix aluco zebrane na 85 stanowiskach. Analiza materiału kostnego wykazała 15152 osobniki drobnych ssaków. Gatunkami, które najsilniej penetrowały aglomerację miejską były: Apodemus agrarius, Mus musculus, Talpa europaea, Rattus norvegicus i Microtus subterraneus. Najbliższe centrum stanowiska tych gatunków znajdowały się w odległości 1,3-2,3 km. Natomiast Microtus agrestis, Mustela nivalis, Arvicola amphibius, Neomys fodiens, Muscardinus avellanarius i Sicista betulina wykazały największy stopień unikania środowisk miejskich, a ich stanowiska najbliższe centrum znajdowały się odpowiednio w odległości: 8,2, 8,6, 8,6, 11,2, 17,8 i 20,2km. Gatunkami, których udział w diecie sów najbardziej zmniejszał się wraz z oddalaniem się od centrum aglomeracji miejskiej, były: A. agrarius i T. europaea, podczas gdy odwrotną zależność wykazano dla M. agrestis i M. avellanarius. Małe ssaki związane z podłożem są wrażliwe na postępującą urbanizację terenu i fragmentację ich środowisk, o czym świadczy fakt, że centralna część aglomeracji warszawskiej była zasiedlana jedynie przez ok. 1/3 gatunków lokalnej fauny.

\section{Słowa kluczowe}

gryzonie, ryjówkokształtne, urbanizacja, miejskie tereny zielone, fragmentacja środowisk 